\title{
Proposal of open field test as a model of varenicline pharmacokinetic study
} in rats

\author{
Julia Zaccarelli-Magalhães ${ }^{\mathrm{i}}$ \\ Thaisa Meira Sandini ${ }^{i i}$ \\ André Rinaldi Fukushima ${ }^{\text {iii }}$ \\ Helenice de Sousa Spinosa ${ }^{\text {iv }}$
}

Registro DOI: http://dx.doi.org/10.22280/revintervol11ed3.398

\begin{abstract}
Varenicline is a medication used for smoking treatment that acts as a partial agonist for nicotinic cholinergic receptors $\alpha 4 \beta 2$ and $\alpha 3 \beta 4$ and as a total agonist of receptor $\alpha 7$ in the central nervous system. Pharmacokinetic is important information for medications that acts in the central nervous system. This kind of assay is commonly done by expensive and complex analytical techniques. Therefore, the aim of this study was to evaluate the possibility of using the open field test as a pharmacokinetic model for varenicline in male rats exposed to a single dose of varenicline. Male rats received a single dose orally (gavage) of three different concentrations of varenicline: 0.03 (therapeutic dose for humans), 0.1 and $0.3 \mathrm{mg} / \mathrm{kg}$ or water (control group). The open field observations were recorded $30 \mathrm{~min}, 1,2,4,6,24,48,72 \mathrm{~h}$ and 7 days after the administration of varenicline or water. The results showed alterations in locomotion and rearing frequencies, as well as in immobility time observed in open field, which is consistent with this drug's plasma peak. Consequently, this behavioral test apparently can be considerate as a model for pharmacokinetic evaluation of varenicline.
\end{abstract}

Keywords: Nicotinic Cholinergic Receptors; Open Field; Pharmacokinetic; Varenicline.

\section{Proposta de utilização do teste de campo aberto como modelo de estudo farmacocinético} de vareniclina em ratos

\section{Resumo}

A vareniclina é um medicamento usado para o tratamento do tabagismo que atua como um agonista parcial dos receptores colinérgicos nicotínicos $\alpha 4 \beta 2$ e $\alpha 3 \beta 4$ e como um agonista total do receptor $\alpha 7$ no sistema nervoso central. A farmacocinética é uma informação importante para medicamentos que atuam no sistema nervoso central. Este tipo de ensaio é comumente feito por técnicas analíticas caras e complexas. Assim, o objetivo deste estudo foi avaliar a possibilidade de utilizar o teste de campo aberto como modelo farmacocinético para a vareniclina em ratos machos expostos a uma dose única de vareniclina. Ratos machos receberam uma dose única por via oral (gavagem) de três diferentes concentrações de vareniclina: 0,03 (dose terapêutica para humanos), 0,1 e $0,3 \mathrm{mg} / \mathrm{kg}$ ou água (grupo controle). 


\section{Revinter}

As observações de campo aberto foram feitas 30 minutos, 1, 2, 4, 6, 24, 48, 72 horas e 7 dias após a administração de vareniclina ou água. Os resultados mostraram alterações nas frequências de locomoção e de levantar, bem como no tempo de imobilidade observado em campo aberto, o que é consistente com o pico plasmático deste fármaco. Consequentemente, este teste comportamental aparentemente pode ser considerado como um modelo para avaliação farmacocinética da vareniclina.

Palavras-chave: Receptores Colinérgicos Nicotínicos; Campo Aberto; Farmacocinética; Vareniclina.

\section{Recebido em 26/06/2018 Aceito em 02/10/2018}

\section{INTRODUCTION}

Varenicline is a medication used for smoking treatment (FAESSEL et al., 2010) that acts as a partial agonist for nicotinic cholinergic receptors $\alpha 4 \beta 2$ and $\alpha 3 \beta 4$ and as a total agonist of receptor $\alpha 7$ (CRUNELLE et al., 2009), promoting the same effects as nicotine, but at a lower intensity, without the effects of withdrawal, and prevents exogenous nicotine from binding to the receptors, blocking the reinforcing effects of its continuous use (ROLLEMA et al., 2010; IIDA et al., 2012).

Researchers have indicated the possible use of varenicline for the treatment of drug abuse, such as alcohol (ERWIN; SLATON, 2014), cocaine (MELLO et al., 2014), amphetamines (VERRICO et al., 2014) and opioids (HOOTEN et al., 2015), due to its modulation in nicotinic cholinergic receptors, which results in different effects in dopaminergic activity and other neurotransmitters systems (MELLO et al., 2014).

Pharmacokinetic is important information for medications that acts in the central nervous system (HENCHOZ et al., 2009). This kind of assay is commonly done by expensive and complex analytical techniques. Therefore, the aim of this study was to evaluate the possibility of using the open field test as a pharmacokinetic model for varenicline in male rats exposed to a single dose of this drug.

The open field is a behavioral test developed by Calvin Hall in 1934 (HALL, 1934). It is widely used to assess motor activity, environmental exploration, anxiety-like behavior, animal emotionality, and other behaviors of several animal species (WALSH; CUMMINS, Revinter, v. 11, n. 03, p. 162-169, out. 2018. 


\section{Revinter}

1976, CHOLERIS et al., 2011, PRUT; BELZUNG, 2003). Considering its wide application, this test can be used to evaluate the plasma decay of drugs that act directly on the general activity, through reducing behavioral parameters.

\section{MATERIALS AND METHODS}

Male Wistar rats (90 days old) were used from the Department of Pathology, School of Veterinary Medicine and Animal Science, University of São Paulo. All rats were housed in pairs in $43 \times 23 \times 16$ polycarbonate cages that were maintained in the specific conditions of a constant 12-hr light/dark cycle (light: 06:00 - 18:00), a controlled temperature $\left(22 \pm 2^{\circ} \mathrm{C}\right)$ and free access to food and water (ZACCARELLI-MAGALHÃES et al., 2018).

All animal manipulations followed the Ethical Principles in Animal Research that were adopted by the Ethics Committee on the Use of Animals by the School of Veterinary Medicine and Animal Science of the University of São Paulo (protocol no. 3304041214).

Varenicline tartrate was obtained from the commercial product Champix ${ }^{\circledR}$ (Pfizer) and was dissolved in tap water. The rats were divided in four groups: three experimental groups that received a single dose of varenicline $(0.03,0.1$ or $0.3 \mathrm{mg} / \mathrm{kg})$ and a control group that received water by gavage ( $\mathrm{n}=10$ animals/group) in volumes that did not exceed $1.0 \mathrm{ml} / \mathrm{kg}$ body weight. The administration occurs between 9 and 10 p.m.

The open field test was conducted in a round arena as described by Sandini et al., 2014. Hand-operated counters were used to score locomotion frequency (the number of floor sections entered), rearing frequency (the number of times the animal stood on its hind legs) and grooming frequency (the number of times the animal touched its forepaws to the head and snout). A chronometer was used to measure the duration of immobility (the total time in seconds without spontaneous movement).

Each rat was placed in the center of the arena, and its behavioral parameters were recorded for $5 \mathrm{~min}$. The observations were recorded $30 \mathrm{~min}, 1,2,4,6,24,48,72 \mathrm{~h}$ and 7 days after the administration of varenicline or water. The arena was cleaned with a $5 \%$ ethanol solution before each test. Control and experimental rats were intermixed for all observations. The videos were analyzed later by two double-blinded observers. 


\section{Revinter}

The data were analyzed with the software GraphPad Prism 6 for Windows (GraphPad Software, Inc., San Diego, CA, USA). The Bartlett test was used to verify the homoscedasticity of the data. Two-way ANOVA with repeated measures were used followed by the Bonferroni post-test, for two factors (treatment and time) evaluation. The results were expressed as the means \pm standard errors, and the differences among the means were statistically significant at $\mathrm{p}<0.05$.

\section{RESULTS}

There were no significant differences in the locomotion frequency of rats between the treatments $(\mathrm{F}(3,36)=2.374, \mathrm{p}>0.05)$, but there were significant differences in time $(\mathrm{F}(8,288)$ $=51.900, \mathrm{p}<0.0001)$ without interaction $(\mathrm{F}(24,288)=1.195, \mathrm{p}>0.05)$. Results showed increase in locomotion frequency of animals that received $0.3 \mathrm{mg} / \mathrm{kg} 6 \mathrm{~h}$ after the drug administration compared to the control group $(\mathrm{p}<0.05)$ - Figure 1.

Regarding rearing frequency, there were no significant differences between the treatments $(\mathrm{F}(3,36)=1.298, \mathrm{p}>0.05)$, but there were significant differences in time $(\mathrm{F}(8,288)$ $=73.410, \mathrm{p}<0.0001)$, without interaction $(\mathrm{F}(24,288)=1.494, \mathrm{p}>0.05)$. Results showed increase in rearing frequency of animals that received $0.1 \mathrm{mg} / \mathrm{kg} 30 \mathrm{~min}$ after the drug administration compared to the control group $(\mathrm{p}<0.05)$ - Figure 1.

Regarding immobility time, there were significant differences between treatments ( $\mathrm{F}$ $(3,36)=3.652, \mathrm{p}<0.05)$, time $(\mathrm{F}(8,288)=29.380, \mathrm{p}<0.0001)$ with interaction $(\mathrm{F}(24,288)$ $=1.647, \mathrm{p}<0.05)$. Results showed decreased immobility time of animals that received $0.1 \mathrm{mg} / \mathrm{kg}$ $2(\mathrm{p}<0.05), 4(\mathrm{p}<0.05)$ and $6(\mathrm{p}<0.01) \mathrm{h}$ after drug administration and of animals that received $0.3 \mathrm{mg} / \mathrm{kg} 4(\mathrm{p}<0.01), 6(\mathrm{p}<0.0001)$ and $72(\mathrm{p}<0.05) \mathrm{h}$ after drug administration compared to the control group - Figure 1. The grooming frequency did not show significant differences between groups (data not showed).

Figure 1 - General activity in the open field of rats that received or not (control) a single dose of varenicline $(0.03,0.1$ or $0.3 \mathrm{mg} / \mathrm{kg})$ by gavage. The means and their standard errors are displayed. $\mathbf{n = 1 0}$ animals/group. 


\section{Revinter}
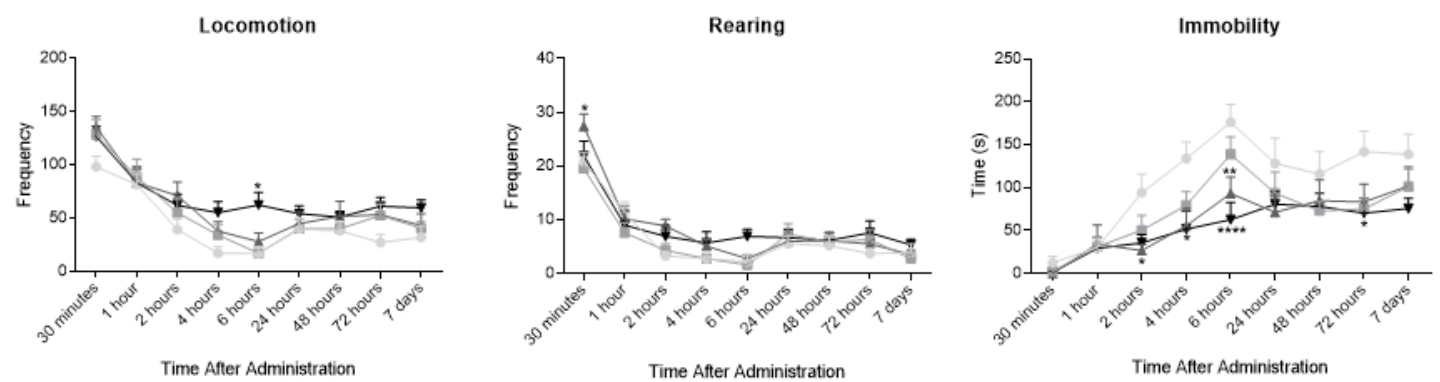

Time After Administration

Control $-0.03 \mathrm{mg} / \mathrm{kg} \leftarrow 0.1 \mathrm{mg} / \mathrm{kg} \rightarrow 0.3 \mathrm{mg} / \mathrm{kg}$

${ }^{*} \mathrm{p}<0.05, * * \mathrm{p}<0.01, * * * \mathrm{p}<0.001, * * * * \mathrm{p}<0.0001$, two-way ANOVA with repeated-measures followed by Bonferroni post-test.

\section{DISCUSSION}

The parameters used to evaluate the animals in the open field were locomotion, rearing, grooming and immobility. Locomotion and rearing are related to exploratory behavior; an increase in these parameters may indicate greater general activity and lower degree of emotionality. Grooming is a behavior expressed in situations where the animal is not afraid, being related to animal emotionality (VALLE, 1972). Immobility reflects a high degree of anxiety and fear, since the longer the animals remains immobile, the greater the degree of anxiety (BERNARDI; PALERMO-NETO, 1980).

The results show that a single dose of varenicline was able to cause few changes in the behavior of rats observed in the open field. There was an increase in the locomotion frequency of the animals that received $0.3 \mathrm{mg} / \mathrm{kg} 6 \mathrm{~h}$ after administration and a decrease in immobility time of animals that received $0.1 \mathrm{mg} / \mathrm{kg}(2,4$ and $6 \mathrm{~h}$ after administration) and $0.3 \mathrm{mg} / \mathrm{kg}(4,6$ and $72 \mathrm{~h}$ after administration). These data indicate a slight increase in the general activity of animals that received the highest doses of varenicline, probably due to this drug's plasma peak, since it is known to occur around 3 to $4 \mathrm{~h}$ after administration in rats (FAESSEL et al. 2008).

Turner et al. 2010 showed that $1 \mathrm{mg} / \mathrm{kg}$ of varenicline resulted in hyperlocomotion of rats in the homecage. Zaniewska et al., 2008 showed that varenicline $(0.3-3 \mathrm{mg} / \mathrm{kg}$, subcutaneous) by itself enhanced the basal locomotor activity in rats. Our results are in accordance with these studies. Consequently, this behavioral test apparently can be used as a Revinter, v. 11, n. 03, p. 162-169, out. 2018. 


\section{Revinter}

model for evaluation of medication pharmacokinetics, as long as the substance acts on animal's general activity. This new proposed of open field use would reduce the cost and complexity of pharmacokinetics studies for new drug and also reduce animal suffering, since the current tests are very invasive.

\section{ACKNOWLEDGEMENTS}

This work was supported by FAPESP (São Paulo Research Foundation) [grant number 2015/05049-3], CAPES (Coordenação de Aperfeiçoamento de Pessoal de Nível Superior) and CNPq (Conselho Nacional de Desenvolvimento Científico e Tecnológico) [grant number 305500/2013-9]. This work is part of the first author master's dissertation in the Graduate Program of Experimental and Compared Pathology, Department of Pathology, School of Veterinary Medicine and Animal Science, University of São Paulo.

\section{References}

BERNARDI, M.M.; PALERMO-NETO, J. Atividade geral: conceito e medidas. Psicologia, v.6, p.43-55, 1980.

CHOLERIS, E.; THOMAS, A.W.; KAVALIERS, M.; PRATO, F.S. A detailed ethological analysis of the mouse open field test: effects of diazepam, chlordiazepoxide and an extremely low frequency pulsed magnetic field. Neuroscience \& Biobehavioral Reviews , v.25, p.235$260,2011$.

CRUNELLE, C.L.; MILLER, M.L.; BRUIN, K.; BRINK, W.; BOOIJ, J. Varenicline increases striatal dopamine D2/3 receptor binding in rats. Addiction Biology, v.14, p.500$502,2009$.

ERWIN, B.L.; SLATON, R.M. Varenicline in the treatment of alcohol use disorders. Annals of Pharmacotherapy, v.48, p.1445-1455, 2014.

FAESSEL, H.M.; BURSTEIN, A.H.; TROUTMAN, M.D. Lack of a pharmacokinetic interaction between a new smoking cessation therapy, varenicline, and digoxin in adult smokers. European Journal of Clinical Pharmacology, v.64, p.1101-1109, 2008.

FAESSEL, H.M.; OBACH, R.S.; ROLLEMA, H.; RAVVA, P.; WILLIAMS, K.E.; BURSTEIN, A.H. A review of the clinical pharmacokinetics and pharmacodynamics of varenicline for smoking cessation. Clinical Pharmacokinetics, v.49, p.799-816, 2010.

HALL, C.S. Emotional behavior in the rat: defecation and urination as measures of individual differences in the emotionality. Journal of Comparative Physiology, v.18, p.385-403, 1934. 
HENCHOZ, Y.; BARD, B.; GUILLARME, D.; CARRUPT, P.; VEUTHEY, J.; MARTEL, S. Analytical tools for the physicochemical profiling of drug candidates to predict absorption/distribution. Analytical and Bioanalytical Chemistry, v.394, p.707-729, 2009.

HOOTEN, W.M.; WARNER, D.O. Varenicline for opioid withdrawal in patients with chronic pain: A randomized, single-blinded, placebo controlled pilot trial. Addictive Behaviors, v.42, p.69-72, 2015.

IIDA, M.; IIDA, H.; TAKENAKA, M.; TANABE, K.; IWATA, K. Preventive effect of varenicline on impairment of endothelial function in cerebral vessels induced by acute smoking in rats. Journal of Anesthesia, v.26, p.928-931, 2012.

MELLO, N.K.; FIVEL, P.A.; KOHUT, S.J.; CARROLL, F.I. Effects of chronic varenicline treatment on nicotine, cocaine, and concurrent nicotine+cocaine self-administration.

Neuropsychopharmacology, v.39, p.1222-1231, 2014.

PRUT, L.; BELZUNG, C. The open field as a paradigm to measure the effects of drugs on anxiety-like behaviors: a review. European Journal of Pharmacology, v.463, p.3- 33, 2003.

ROLLEMA, H.; SHRIKHANDE, A.; WARD, K.M.; TINGLEY II, F.D.; COE, J.W.; O'NEILL, B.T.; TSENG, E.; WANG, E.Q.; MATHER, R.J.; HURST, R.S.; WILLIAMS, K.E.; DE VRIES, M.; CREMERS, T.; BERTRAND, S.; BERTRAND, D. Pre-clinical properties of the $\alpha 4 \beta 2$ nicotinic acetylcholine receptor partial agonists varenicline, cytisine and dianicline translate to clinical efficacy for nicotine dependence. British Journal of Pharmacology, v.160, p.334-345, 2010.

SANDINI, T.M.; UDO, M.S.B.; REIS-SILVA, T.M.; BERNARDI, M.M.; SPINOSA, H.S. Prenatal exposure to integerrimine N-oxide impaired the maternal care and the pshysical and behavioral development of offspring rats. International Journal of Developmental Neuroscience, v.36, p.53-63, 2014.

TURNER, J.R.; CASTELLANO, L.M.; BLENDY, J.A. Nicotinic partial agonists varenicline and sazetidine-a have differential effects on affective behavior. Journal of Pharmacology and Experimental Therapeutics, v.334, p.665-672, 2010.

VALLE, F.P. Rats performance on repeated test in open-field as a function of age. Psychological Science, v.23, p.333-335, 1972.

VERRICO, C.D.; MAHONEY, J.J.; THOMPSON-LAKE, D.G.; BENNETT, R.S.; NEWTON, T.F.; DE LA GARZA, R. Safety and efficacy of varenicline to reduce positive subjectiveeffects produced by methamphetamine in methamphetamine-dependentvolunteers. International Journal of Neuropsychopharmacology, v.17, p.223-233, 2014.

WALSH, R.N.; CUMMINS, R.A. The open-field test: a critical review. Psychological Bulletin, v.83, p.482-504, 1976.

ZACCARELLI-MAGALHÃES, J.; MOREIRA, N.; SANDINI, T.M.; ABREU, G.R.; SANCHEZ-SARMIENTO, A.M.; RICCI, E.L.; FUKUSHIMA, A.R.; SPINOSA, H.S. Evaluation of prolongued exposure to varenicline in adult rats: heamatological, biochemical and anatomopathological studies. Basic \& Clinical Pharmacology \& Toxicology, v.122, p.305-309, 2018. 


\section{Revinter}

ZANIEWSKA, M.; MCCREARY, A.C.; STEFANSKI, R.; PRZEGALINSKI, E.; FILIP, M. Effect of varenicline on the acute and repeated locomotor responses to nicotine in rats. Synapse, v.62, p.935-939, 2008.

\footnotetext{
' Graduação em Ciências Biológicas pela Universidade Presbiteriana Mackenzie; Mestrado em Ciências pela Universidade de São Paulo; Doutoranda em Patologia Experimental pela Universidade de São Paulo.

ii Graduação em Farmácia pela Universidade Estadual do Centro-Oeste; Mestrado e Doutorado em Toxicologia e Análises Toxicológicas pela Universidade de São Paulo

iii Graduação em Farmácia pela Universidade São Judas Tadeu; Mestrado em Toxicologia e Análises Toxicológicas pela Universidade de São Paulo; Doutorado em Patologia Experimental e Comparada pela Universidade de São Paulo.

iv Graduação em Medicina Veterinária pela Universidade de São Paulo; Mestrado e Doutorado em Fisiologia pela Universidade de São Paulo. E-mail para contato: hspinosa@usp.br
} 